Lexis Vol. XLV (1) 2021: 347-376

\title{
Ficciones del territorio: escritura y paisaje(s) en Tratado de arqueología peruana de Roberto Zariquiey"
}

\author{
Biviana Hernández \\ https://orcid.org/0000-0003-4453-7005 \\ Centro de Estudios Avanzados, Universidad de Playa Ancha \\ biviana.hernandez@upla.cl
}

\section{RESUMEN}

En este artículo abordaremos la condición interdisciplinaria de Tratado de arqueología peruana de Roberto Zariquiey desde la noción de territorio como espacio referencial de la geografía y cultura peruanas. Nos centraremos, para ello, en algunos de los paisajes que caracterizan a las tres zonas geográficas en que se divide el territorio nacional del Perú —costa, sierra, selva- y que resultan claves para entender las dos dimensiones en que opera la textualidad de este poemario-tratado: como reescritura de los significados subjetivos de las comunidades del pasado y como apropiación de los códigos/lenguajes de las ciencias sociales para producir un texto oscilante, o en mutación entre poesía y arqueología.

Palabras clave: poesía peruana, interdisciplina, reescritura, territorio, paisaje

"Este artículo forma parte del Proyecto FONDECYT Iniciación N 11170009, "Reescribir o el comienzo de la escritura: poéticas del campo cultural chileno-peruano (1943-2016)", del cual soy investigadora responsable.

https://doi.org/10.18800/lexis.202101.010 
Fictions of the Territory: Writing and Landscape(s) in Tratado de arqueología peruana by Roberto Zariquiey

\begin{abstract}
In this article we will address the interdisciplinary condition of Roberto Zariquiey's Tratado de arqueología peruana from the notion of territory as a referential space of Peruvian geography and culture. To this end, we will focus on some of the landscapes that characterize the three geographical areas in which the national territory of Peru is divided - the Costa, the Sierra, the Selva-, and which are key to understanding the two dimensions in which the textuality of Zariquiey's poetry-treatise: as a rewriting of the subjective meanings of the communities of the past and as an appropriation of the code / language of the social sciences to produce a text that oscillates between poetry and archeology.

Keywords: Peruvian poetry, interdiscipline, rewriting, territory, landscape
\end{abstract}

\title{
1. A modo de introducción
}

Como expresión de una literatura antropológica ${ }^{1}$, Tratado de arqueología peruana (2005) de Roberto Zariquiey (Lima, 1979) es un texto fluctuante entre poesía y arqueología que se articula como un tratado poético o, mejor, como una ficción poética del paisaje(s) y territorio(s) peruanos. En estas páginas, revisaremos las características de ese paisaje/territorio, considerando la postura ${ }^{2}$ enunciativa

\footnotetext{
1 La literatura antropológica ha sido caracterizada como interdisciplinaria e intercultural, en la medida en que se mueve en pares, entre dos disciplinas (que también pueden llegar a entenderse como "culturas disciplinares"), y entre dos culturas, la del sujeto y la del otro. Un aspecto fundamental de la textualidad, destacado sobre todo desde la mirada de las ciencias sociales, es que corresponde a una manifestación de un proceso antropológico centrado en el encuentro y el conocimiento del otro, ya sea desde una situación de trabajo de campo (como delimita la teoría de la antropología poética), o desde una situación textual (como posibilidad que defiende la antropología literaria) (Valenzuela 2015: 167).

La discusión crítica sobre esta categoría y otras asociadas, como literatura intercultural, poesía antropológica o antropología poética, se encuentra en Alvarado 2005; Carrasco 2003, 2005; Degregori 2000; Fernández Cozman 2016; López-Baralt 2005; Olivares 1995, entre otros.

2 Postura como dimensión performativa (una puesta en escena de la figura de autor) y discursiva (construcción de una imagen social) que le permite al escritor ocupar una
} 
del yo hablante y su trabajo interdisciplinario con la palabra, entre poesía y arqueología; esto es, el tratamiento del espacio referencial a partir de los modos en que opera la (re)escritura de la geografía: por un lado, desde los "significados subjetivos de una comunidad humana del pasado" (Zariquiey 2005: 9), o cómo el ejercicio de actualización/interpretación del presente a partir del pasado remite, inequívocamente, a la historia del Perú contemporáneo; y, por otro lado, desde la apropiación de los códigos/lenguajes de las ciencias sociales, específicamente, de la arqueología, en circunstancias en que es desde este saber que se inicia el poemario con el epígrafe que reproduce las palabras del arqueólogo británico Ian Hodder, a quien se toma como referente teórico de la idea crítica de arqueología, y con el que Zariquiey da comienzo al libro y a su recorrido geográfico: "Sólo cuando planteamos hipótesis acerca de los significados subjetivos presentes en la mente de una comunidad humana del pasado podemos empezar a hacer arqueología” (Zariquiey 2005: 9).

\section{Primera aproximación al territorio: geografía y comunidad}

En la tradición literaria peruana existe una rica y variada producción en torno a representaciones poéticas de la nación. Desde Baladas peruanas (1935) de Manuel González Prada hasta Comentarios reales (1964) de Antonio Cisneros, Cementerio general (1989) de Tulio Mora, Symbol (1991) de Róger Santiváñez, Zona Dark (1991) de Montserrat Álvarez, Las armas molidas (1996) de Juan Ramírez Ruiz o Una procesión entera va por dentro (1998) de Rodrigo Quijano, existe una línea de sentido que le da continuidad

\footnotetext{
posición determinada dentro del campo literario y cultural, “y que se erige a la vez en un espacio transicional entre lo individual y lo colectivo y en un punto de ensamblaje entre lo textual y lo extra-textual" (Guerrero 2018: 155). La propio de la postura, asevera Guerrero, es asociar, por un lado, una dimensión performativa y actancial que reúne todo lo que participa de una puesta en escena pública, como las apariciones mediáticas de un autor, y, por otra parte, está la dimensión propiamente discursiva, textual, aquello que la retórica antigua definió como el ethos: la estampa que un locutor da de sí mismo a través de su discurso, de su poética, de los géneros literarios que practica, de sus narradores y personajes (2018: 155).
} 
a la exploración de los vínculos entre escritura, historia y memoria. Asimismo, en lo que va del siglo XXI es posible cotejar ese hilo discursivo en textos como $Y$ a nadie incendia el mundo (2005) de Victoria Guerrero, Las hijas del terror (2007) de Rocío Silva Santisteban, Procesos autónomos (2016) de Manuel Fernández o Persona (2017) de José Carlos Agüero, por mencionar solo algunos. En esa constelación, Tratado de arqueología peruana de Roberto Zariquiey propone una mirada espacial del territorio peruano a partir de su división en tres grandes zonas geográfico-culturales: la costa o desierto costero, la sierra o región andina y la selva o región amazónica; zonas que se observan, experimentan y exploran como sustrato de una “consciencia paisajera” (Miranda e Ibáñez 2018), donde el poeta se relaciona con los entornos desde un deseo y una poética del habitar en tanto pertenencia y sentido de comunidad.

El poemario recorre el territorio nacional desde esta tripartición geográfica para dar consistencia argumentativa a lo que el título de la obra propone o anuncia: hacer un tratado de arqueología peruana in situ, conforme el sujeto enunciante - un aprendiz de arqueólogo ${ }^{3}$ realiza su recorrido en un viaje de iniciación y hasta de formación que le permitirá aproximarse a la historia - y la(s) microhistoria(s) — desde una visión crítica tanto de la poesía como de la arqueología, partiendo por la apropiación del lenguaje y códigos de la ciencia social, valga decir, la organización del tratado según la forma de una investigación o bitácora de trabajo que se hará explícita desde el índice: primero, el Marco teórico, un breve poema en el que se sintetiza la visión o postura ético-poética desde la cual se trama la textualidad del poemario-tratado: "pensar en el Perú como se piensa en un fantasma” (Zariquiey 2005: 13).

\footnotetext{
Seguimos la observación de Luis Fernando Chueca, para quien en este libro hay varios niveles y varios sujetos poéticos, pero el personaje fundamental, el hablante básico, es el que aparece en la ficción del texto como un joven aprendiz de arqueólogo, que, a la par que recorre el territorio nacional [...] descubre los saberes de esa ciencia que le va permitiendo avanzar en su proyecto de un Tratado de arqueología peruana. Este personaje, a quien se puede reconocer como un representante del poeta en el texto, cita, a su vez, la palabra de algunos arqueólogos, conferenciantes, narradores orales y otros individuos, que son importantes en su aprendizaje (2007: 84).
} 
Luego, la sección central correspondiente al desarrollo o análisis del objeto de estudio (las zonas geográficas del Perú), siendo la primera zona, la costa, donde se enuncia, también en forma poética, una introducción del primer capítulo y una suerte de contextualización y antecedentes de la materia abordada mediante los relatos: "La arqueología contextual en Puerto Inca y Chala" y "Dos estudios sobre antiguas huellas humanas en la costa”. Por último, está la metodología de investigación que desarrollan los textos: "El paso previo: la prospección arqueológica" y "Metodología para la seriación de los objetos aparecidos en un contexto ritual", y la conclusión del capítulo de la costa con las "Reflexiones arqueológicas" del hablante. Cada sección del texto, además, contiene su propio índice o temario relacionado con los espacios y entornos naturales, sociales y culturales que recorre el aprendiz de arqueólogo, y de los que este irá formulando distintas notas de campo sobre su experiencia de observación y documentación etnográfica.

De la totalidad del recorrido, nos detendremos en algunos pasajes/paisajes de estas tres zonas geográficas que resultan claves para entender las dos dimensiones o niveles en que, como ya hemos señalado, opera la textualidad de Tratado de arqueología peruana: como reescritura de los significados subjetivos de las comunidades del pasado y como apropiación de los códigos/lenguajes de las ciencias sociales para producir un texto fluctuante entre dos tipos de saberes y formas de expresión: poesía y arqueología.

\section{La costa: los inicios del recorrido, el proyecto de escritura}

La arqueología contextual ${ }^{4}$ que practica el aprendiz de arqueólogo de Tratado de arqueología peruana comienza en el "Capítulo

\footnotetext{
4 Para Hodder, la práctica de la arqueología contextual propicia distintos tipos de significados, que van desde los procesos estructurados de las relaciones sociales y económicas hasta los contenidos estructurados de los códigos simbólicos. En el marco de un análisis contextual, estos dos tipos de significado pueden llamarse, a su vez, contextuales [...] El primer tipo de significado contextual hace referencia al contexto del medio físico y del comportamiento presente en la acción [...] En segundo lugar, el contexto puede significar "con-texto" y así la palabra introduce una analogía entre los significados con-
} 
del principio. En la arena de Puerto Inca”, donde este se da a la tarea de elaborar una "breve constatación de las creencias de sus pobladores” (Zariquiey 2005: 21). ${ }^{5}$ En este primer recorrido por la geografía física y humana de la costa, el hablante poético utiliza el registro etnográfico para tomar nota de las creencias populares (mitos, supersticiones, señales divinas o mágicas) que sostienen los pobladores en las distintas comunidades costeras que habitan. Llama la atención, al respecto, que la primera constatación de estas creencias parte con un mal augurio: "hoy amaneció en la orilla - y entre nosotros- un ave muerta" (Zariquiey 2005: 21), en circunstancias en que para algunos de los pobladores, a quienes el hablante da la palabra, "estábamos ante un oscuro designio de Dios / y ante una señal suya" (Zariquiey 2005: 22); oscuro designio que marcará el derrotero de su viaje, ya por los diversos paisajes de la geografía así como por los peculiares territorios de la escritura.

El poema termina con una "conclusión arqueológica", donde el sujeto enunciante expresa que "como los de hoy, su amor al mar habrán tenido / los antiguos pobladores del Perú. También así su respeto" (Zariquiey 2005: 22); conclusión que, a su vez, se cierra con una nota al pie de página: "La llovizna duró tres noches" (Zariquiey 2005: 22), como constatando las creencias de los pobladores de Puerto Inca: las señales de adversidad que anunciaba la presencia del ave muerta en la playa. En este sentido, podría decirse que la nota al pie actúa como evidencia etnográfica del propio hablante-aprendiz de arqueólogo que no solo intenta practicar una arqueología contextual de los espacios, sino que también se incluye dentro del objeto

textuales de los rasgos de la cultura material y los significados de las palabras en una lengua escrita (1994: 163-164).

5 Como casi todos los métodos etnográficos que se emplean en el poemario-tratado de Zariquiey desde la práctica de una arqueología contextual, el hablante aporta una cita-epígrafe al comienzo del poema para que los lectores comprendan en qué sentido se entiende aquí la noción de creencia: "Para Frazer, el que una creencia concreta fuera o no religiosa dependía del grado en que los participantes creían poder lograr que una entidad o fuerza obedeciera sus órdenes. Si la actitud de los participantes era de incertidumbre y humildad $[\ldots]$ entonces sus creencias y acciones eran esencialmente religiosas. Marvin Harris" (Zariquiey 2005: 21). 
estudiado como significado subjetivo de la comunidad humana del pasado/presente que investiga. De su recorrido por el territorio espera y aspira a aprender las técnicas del oficio, pero también a elaborar un espacio simbólico de memoria que el mismo recorrido dejará en evidencia a través de los restos encontrados en el paisaje/ territorio peruano en tanto memoria del pasado, señal "oscura" del presente y predicción, probablemente, de lo por venir.

Siguiendo las pistas de las observaciones iniciales, "El Capítulo del medio. Todavía en puerto Inca", se presenta como una nota de campo que discurre sobre lo acontecido con el ave muerta, presagio de que alguna tragedia o catástrofe se avecina, inminente: "el Océano Pacífico susurra su reniego / y por momentos se muerde la lengua / y no se le oye / pero se puede percibir / cómo oculta su dolor / en los caminos delineados por la espuma // cómo su ronquido doloroso se hace blanco" (Zariquiey 2005: 23). Como en la conclusión arqueológica del poema anterior, en la anotación que cierra este poema-capítulo se lee la reflexión del yo poético en la misma dirección: "[...] pienso ahora en la posibilidad de que su arribo haya sido simplemente el fruto inaminado [sic] de la furia sostenida de las aguas y no el signo visible del designio de alguien" (Zariquiey 2005: 23). El sujeto interpreta, desde su condición de poeta, el signo adverso que los pobladores habían asumido como una señal funesta de la naturaleza en los dos poemas-notas que cubren "El Capítulo del final. Chala (a pocos kilómetros de Puerto Inca)". La primera nota, "1 Sobre sus ruinas", describe la manera en que los pobladores construyen humildemente sus casas sobre rocas, barro y conchas molidas que arroja el mar, "todo para que sus casas / duren más que ellos / y reciban entre nosotros / la triste denominación de ruinas" (Zariquiey 2005: 24). Mientras que la nota 2, "Sobre sus muertos", elabora una emotiva reflexión sobre los malos augurios que anuncia el vuelo de las aves de carroña: "cuando una ataque / querrá decir / que es tarde y que hemos muerto / nuestros cuerpos serán desde ese instante / patrimonio de la arqueología peruana" (Zariquiey 2005: 25). En ese "querrá decir" de la voz escuchada por el aprendiz de arqueólogo, percibimos el modo en que 
actúa el ejercicio de la arqueología poética como (re)construcción de los significados subjetivos del pasado y de la propia escritura: no hay evidencia objetiva de los hechos del pasado, en concordancia con la no objetividad de la memoria y del lenguaje empleado en el presente. De esta manera, lo que el pasado signifique dependerá, sustancialmente, del tipo de percepciones que el observador, en este caso el poeta, realice en el lugar de los hechos que investiga, y de los alcances simbólicos que estas percepciones adquieran en el marco de la comunidad de referencia.

De acuerdo con la interpretación de estas señales y las "breves constataciones" del aprendiz del arqueólogo, los "Dos estudios sobre antiguas huellas humanas en la costa": "I litoral del Perú" y "II los cangrejos de la playa El Colorado", van a producir la visión fantasmal o mortuoria del Perú que anticipaba el marco teórico del tratado, por medio de las imágenes de muerte y dolor que envuelven al territorio nacional y que en esta sección del tratado de Zariquiey aparecerán vinculadas, todas, al mar: "se escucha el gruñido del Pacífico / enfurecido por haber tenido que arribar / a costas tan golpeadas como éstas / y por tener que acercarse diariamente / a cuerpos tan enfermos y tan tristes / como los de mis compatriotas" (Zariquiey 2005: 27). Si en los poemas anteriores el hablante empatizaba con los pobladores de Puerto Inca, sintiéndose uno más de la comunidad, en estos dos estudios va a declarar su sentimiento de fraternidad al referirse a ellos como "mis compatriotas", sujetos a quienes percibe en su calidad de cuerpos "tan enfermos y tan tristes” como lo está el mismo Pacífico que gruñe de dolor. Naturaleza y cultura, el territorio como paisaje físico, humano y social, se expresa aquí como designio oscuro, otra vez, de esa fatalidad que envuelve al territorio-nación peruano.

Frente a esas señales, los pobladores dicen haber perdido la fe: "veintitantos millones de personas / hemos decidido enterrarla / como a un hermano muerto" (I litoral del Perú, 27), impactante declaración que enfatiza las imágenes de muerte que atraviesan la dimensión afectiva y espiritual de la comunidad, desde la facticidad del espacio natural que emplaza la imagen iterativa del 
mar. La comunidad decide, entonces, “enterrar” la fe como a un "hermano muerto", destacando la cantidad de personas que la componen: "veintitantos millones" que expresan el dolor generalizado de la pérdida. No tener fe equivale, en este contexto, a perder el sentido de la esperanza y del propio pasado, que es la memoria y la historia viva compartida; sentimiento que también se expresa en el segundo poema-estudio, donde el hablante observa a los cangrejos $^{7}$ en la playa El Colorado (Huacho-Perú) y ve en ellos, en su manera de cavar y construir sus hogares bajo profundos y estrechos agujeros, un reflejo de la muerte que cunde: "como si fueran ellos mismos muertos que se entierran [...] (¿será que de ellos / los antiguos habitantes de la costa / aprendieron sus usos funerarios?)" (Zariquiey 2005: 28). ${ }^{8}$ La posibilidad de que se trate de muertos que se entierran a sí mismos se plantea en el poema "Prospecciones desde la casa de la abuela”, en el que se expresa la aflicción del entorno con su flora y fauna sufrientes: "[...] cangrejos entristecidos / y el silencio de la playa / mordida nuevamente" (Zariquiey 2005: 32). Es de destacar las potentes imágenes de dolor que plantean estos versos: “malecones destruidos”, “doloridos pescadores”, "cangrejos entristecidos”, "el silencio de la playa / mordida nuevamente”.

Las imágenes mortuorias del hombre y la naturaleza en su conjunto alcanzan a los sitios de memoria. Así se observa en "El capítulo metodología para la seriación de los objetos aparecidos en un contexto ritual", donde el aprendiz de arqueólogo, refiriéndose al sitio arqueológico de Pachacamac, describe su vana “oscura” labor de

\footnotetext{
6 Según el Instituto Nacional de Estadística e Informática (INEI), se estima que la población del país andino asciende a 31.237.385 habitantes, cifra que arrojan los resultados de los Censos Nacionales de 2017.

Más adelante, en los relatos de la sierra, específicamente en el poema “Arqueología e historia. Oración apócrifa al Apu Wiracocha”, el hablante se refiere a los cangrejos como seres dotados de voluntad divina: "tú que dijiste a los cangrejos / que era propio de animales con tenaza / avanzar siempre mirando / aquello que ha quedado detenido" (Zariquiey 2005: 47).

8 Como varios otros, este poema contiene una nota al pie de página que profundiza el simbolismo de las imágenes marinas de la costa, principalmente la figura de los cangrejos que "cavan sin cansancio / casas que / mañana serán cubiertas / por el agua / por la arena / o por algún muchachito inquieto que juega a molestarlos” (Zariquiey 2005: 28).
} 
la siguiente manera: “(cuerpos enterrados desde hace tantos años) / limpio cada hueso / cada trasto embolso / y me marcho // todo a mi alrededor ha sido enumerado y es en vano // ésa es la oscura labor del arqueólogo" (Zariquiey 2005: 33). Así como el entorno es descrito mediante imágenes de penumbra y ruina, el oficio mismo de la ciencia social está teñido de oscuridad y atisbos de muerte, pero también de inutilidad, como si en el fondo el poeta-etnógrafo supiera que todo intento de llevar a cabo su tratado de arqueología peruana será infructuoso y no arrojará ningún hallazgo o descubrimiento que permita cambiar el estado de cosas al que se enfrenta en su recorrido de aprendizaje, el que, por cierto, solo le va dando pistas de fracaso, pesar y vacío. Aun así, sus "Reflexiones arqueológicas" , que cierran el capítulo de la metodología, plantean una mirada optimista y hasta emotiva en torno al trabajo arqueológico que emprende como trabajo de la memoria: "II [...] porque debajo del mar / hay también tierra / y porque algún día / esa tierra también será sostén de nuestro paso" (Zariquiey 2005: 36). Como se ve, aflora en sus palabras un cierto tono esperanzador que le dará aliento para continuar su viaje-recorrido por el territorio y los paisajes del Perú, y dar término a su proyecto de escritura del tratado.

\section{La sierra: o donde los muertos no son tan antiguos}

El capítulo dedicado a la sierra se abre con "Los diarios de Julio C. Tello", médico y antropólogo peruano a quien se atribuye el descubrimiento de las culturas arqueológicas del antiguo Perú, Chavín (Andes centrales, departamento de Ancash, 1200-200 a. C.) y Paracas (región Ica, provincia de Pisco, costa centro-sur del Perú, entre los años 850 a. C. y 200 d. C.). Se observa aquí un cambio importante de registro enunciativo, pues, si en la primera sección, la costa, accedíamos a las percepciones del hablante principal del poemario-tratado, en esta tendrá lugar la presencia de varias voces

\footnotetext{
9 La segunda reflexión con que se inicia el apartado de las "Reflexiones arqueológicas", tiene una nota al pie de página que indica: "La reflexión I se extravió el 17 de febrero del año 2003" (Zariquiey 2005: 35).
} 
que articularán una mirada más plural sobre el oscuro designio que envuelve al territorio nacional, su historia y memoria.

Desde la ficción de identidad del yo autobiográfico, los diarios de Julio Tello (1880-1947) reproducen la voz del médico y antropólogo peruano por medio de tres poemas que, si bien datan la fecha correspondiente al día y mes calendario en que fueron escritos, dejan indeterminado el año exacto de su escritura al graficarse con puntos suspensivos (19...). La anotación del 18 de febrero se asemeja a la percepción del hablante-aprendiz de arqueólogo en el capítulo anterior cuando observaba a los cangrejos de la playa El Colorado, pues, mientras aquel veía en su forma de excavar una suerte de "auto-enterramiento", este tiene un sueño premonitorio: "mis manos se acercaban a la tierra / era yo el hoyo excavado / era yo lo que mis manos encontraban" (Zariquiey 2005: 39). La voz de Tello parece llegar a la misma observación/constatación del oscuro designio que marca el inicio de Tratado de arqueología peruana: la presencia de la muerte que rodea la vida; la aproximación al Perú desde imágenes fantasmales y mortuorias que constatan, una y otra vez, su ruina y destrucción.

Otra anotación de los diarios de Tello sintetiza la mirada del sujeto enunciante hacia el oficio de la arqueología: “El pasado es una experiencia que hay que volver a vivir por medio de la mente", refrendando la premisa de que "la arqueología marxista se derrumba ante nosotros" (Zariquiey 2005: 41). Esta anotación se plantea como explicación del fracaso de la arqueología en tanto ciencia que reconstruye-o intenta reconstruir - los significados subjetivos de las comunidades del pasado a partir del análisis de su cultura material, en su dimensión factual y simbólica: "El pasado es una experiencia que hay que volver a vivir por medio de un ejercicio silencioso de los sentidos" (Zariquiey 2005: 42). Pero, la cita pone en duda la capacidad de la ciencia arqueológica para llevar a cabo esta misión cuando sus métodos parecen no ser suficientes o los más apropiados para acceder al conocimiento del pasado - experiencia que se vive, según coteja la voz poética, por medio de un ejercicio silencioso de los sentidos-, y poder (re)construir el pre- 
sente a partir de aquel. El poeta-etnógrafo, a través de las voces que se expresan en esta sección del tratado, se va posicionando frente a los saberes adquiridos a medida que recorre el territorio afectiva y críticamente, dejando ver que el método científico debe ser enriquecido por la subjetividad e imaginación del sujeto que investiga.

Esta explicación, que confirma la imposibilidad de la arqueología marxista (Hodder 1994) como estudio de la cultura material para deducir de ella la ideología de los pueblos antiguos, se condice con el apéndice de esta sección del tratado de Zariquiey, en que el hablante refiere el estudio sobre el sitio arqueológico de Chavín de Huántar realizado por otro arqueólogo peruano en 1979, según se indica en el texto. El intelectual habría sido expulsado de la comunidad científica por considerársele subversivo, de ahí surge su interés por reproducir el "contenido exacto del texto que el propio investigador nos proporcionó en una conversación con él, sostenida en su casa de Pachacamac" (Zariquiey 2005: 42). Las supuestas palabras transcritas del arqueólogo en dicha conversación - “En 1979, un arqueólogo peruano escribió un estudio sobre el sitio arqueológico de Chavín de Huántar” (Zariquiey 2005: 42) — se transforman en un poema lírico bajo la forma de una ficción arqueológica, que describe el acto sexual del origen entre una pareja de muchachitos que dan inicio a la cultura milenaria de Chavín de Huántar: "en Chavín de Huántar / uno puede escuchar a la pareja de muchachitos/que hace dos mil quinientos años / esquivando los cuidados de guardias y sacerdotes/llegó hasta la piedra ceremonial / para hacerse el amor [...] / hay arrechura en Chavín de Huántar / pero ni todos los arqueólogos reunidos / podrían darse cuenta" (Zariquiey 2005: 43). El pasado del origen, parecen sugerir los versos, habita en la memoria del aprendiz de arqueólogo que, tal vez por su condición de poeta, logra oír ese pasado primordial en el pálpito de las rocas y en el pulso de la tierra, a diferencia de la comunidad científica que, así como expulsa a quienes se rebelan en contra de sus métodos, desoye, por principio, el lenguaje de la naturaleza.

A continuación, y en contraste con esta disposición a la escucha, accedemos a la voz de otro personaje, correspondiente a alguien 
a quien solo se nombra como "el arqueólogo". Su palabra queda registrada en el relato que el hablante del poema titula "El arqueólogo viaja entre hombres vivos. La etnografía como método de una ciencia de los muertos" ${ }^{10}$ En este relato, el arqueólogo se encuentra con "lo efímero, lo transitorio / lo fugitivo y lo ambiguo" (Zariquiey 2005: 52), cualidades que supone el ejercicio de la práctica arqueológica en terreno: la arqueología contextual entendida como reconstrucción cultural que depende de la atribución de significados subjetivos a los contextos históricos específicos (Hodder 1994: 117). Este personaje explica con las herramientas propias de la disciplina en qué consiste la analogía etnográfica: "El estudioso de la arqueología sabe bien que los hombres del presente ayudan a comprender a los hombres del pasado. A este proceso de mirar en el prójimo para adentrarse en el que ha muerto se le denomina analogía etnográfica” (Zariquiey 2005: 49), técnica con la cual el arqueólogo busca "desentrañar al otro por más viejo que sea su esqueleto” (Zariquiey 2005: 49).

Lo anterior se desarrolla "En presencia de Tiahuanaco", donde el ejercicio de analogía etnográfica solo es posible desde la disposición a escuchar las voces inescrutables de los otros: "amplias son las planicies de Bolivia / cuando uno llega a Tiahuanaco/ y presencia la impronta de los que ya no están / y su herencia de piedra inmensurable /-lo suficientemente pequeña / para habitar nuestro zapato / lo suficientemente vasta / para cubrir con su sombra entristecida / las misteriosas formas de habitar la tierra / que han tenido los humanos-” (Zariquiey 2005: 50). ${ }^{11}$ Sin embargo, el poema siguiente, "Excavación en alguna ruina cuzqueña. La arqueología es en sí misma un encuentro con la muerte", muestra el intento fallido de la escucha o del desentrañamiento del otro cuando lo que se impone, en la práctica, es la terrible constatación de que la arqueología es en si misma un encuentro con la muerte. Estamos

10 Este poema se inicia con la siguiente cita-epígrafe: “Los objetos nos hablan (o quizá sólo nos susurren), el problema se plantea a la hora de su interpretación. Pero no existen gramáticas o diccionarios de los objetos. // Nuevamente Ian Hodder" (Zariquiey 2005: 49). 11 Las cursivas son nuestras. 
una vez más ante el fracaso de la arqueología como recurso y método prospectivo ${ }^{12}$ para (re)construir esa historia del pasado, o esa arqueología de lo humano (los significados subjetivos de sus comunidades) que anima al poeta-aprendiz de arqueólogo de Zariquiey a organizar estas notas de campo en el proyecto de escritura de un tratado de arqueología peruana. Mas, pese a que la evidencia recogida constata que esta es un encuentro con la muerte, el yo no claudica su convicción de hallar vida en la muerte o en la posibilidad de convertir los restos (los huesos de esos cuerpos inanimados) en proyección de futuro, en memoria viva de un pasado u origen cuya herencia es piedra inmensurable: “ésa es la esperanza del arqueólogo: / encontrar momias que digan / muertos que quieran ser otra cosa / y no tanto cadáver” (Zariquiey 2005: 51); esperanza de que los muertos, al fin, vuelvan a tener voluntad y los cadáveres dejen de ser solo vestigio arqueológico, resto fosilizado. Pero, pese a que cierto asomo de esperanza lo hace sonreír - “no necesité ni exigí nada más / tampoco supuse que algo diferente / me fuese a ser dado // por ello sonrío" (Zariquiey 2005: 52)—, dicho sentimiento convive con la silenciosa melancolía del arqueólogo que debe "limpiar cada hueso" (Zariquiey 2005: 51), en esa vana e inútil labor que insiste en afirmar el oscuro designio del territorio cuando no solo las aves y los cangrejos de la costa son signos de muerte, sino también los restos de los cadáveres en la sierra, en los que se inscribe la muerte de los que aún están vivos.

12 En el relato "El paso previo: la prospección arqueológica”, el hablante explica con detalle ciertas metodologías de su trabajo de campo, como la técnica de "prospectar un espacio” que aprendió de una pareja de arqueólogos, Bárbara Carvajal y David Oshige, autores de "un interesante informe que se perdió en los archivos del Instituto Nacional de Cultura (INC) del Perú” (Zariquiey 2005: 31). El sujeto da cuenta de lo que aprende de aquellos y cómo, al mismo tiempo, la práctica prospectiva aclaró la esencia o fundamento de la arqueología contextual que él mismo como aprendiz de arqueólogo pretende llevar a cabo en este tratado:

no podía excavarse aquello que no había sido previamente caminado con ojo prospectivo. Así, pasamos una larga temporada en Magdalena, observando casas, parques, avenidas y automóviles [...] Magdalena era entonces un distrito moderno y lleno de edificios. "Aún así — me explicaron ellos— puede percibirse niños antiguos corriendo hacia el mar y hombres y mujeres, antiguos también, que también se aproximan a la playa” (Zariquiey 2005: 31). 
La reflexión anterior continúa en las dos partes en que se divide el poema "Cuando los muertos no son tan antiguos. Hacia una arqueología de lo contemporáneo”, que desde su título busca extender el cronotopo espacio-temporal del pasado hacia el presente y futuro, yendo de lo más remoto a lo más actual. En la primera parte del poema el hablante se refiere a la ciudad de Yungay, fundada en 1970, en la que "las voces que se escuchan en sus calles no son voces / sino el eco repetido de algo que ya no está” (Zariquiey 2005: 53). El origen se ha perdido y la memoria es receptáculo de una ausencia que se proyecta en una ciudad vacía, sin pasado que recordar. Elocuente resulta, sobre ello, la contemplación del paisaje, antes de excavar el suelo, buscando "lo que / debajo de nosotros permanece // los paisajes en el Perú son tumbas enormes y calladas" (Zariquiey 2005: 54). Lo que permanece, según la observación del arqueólogo, son las tumbas, los cadáveres que quedan ahí sepultados como restos de un pasado inmensurable e inaccesible. Probablemente, en este verso es donde mejor se representa la condición del territorio nacional como ese fantasma que preanunciaba el marco teórico del tratado: un alma en pena que revive en las creencias de sus pobladores, así como también en la observación/constatación de esos restos que permanecen como las únicas huellas del latrocinio que han dejado las guerras. Porque esos huesos/cadáveres —únicos restos de la cultura material del pasado, en la sierra- no son tan antiguos a ojos del arqueólogo que los examina en presente.

La segunda parte del poema completa este sentido mortuorio del territorio-nación cuando el hablante, por boca del arqueólogo, nombra a las fuerzas armadas antimotines del Perú, los Sinchis, unidad paracaidista de la policía nacional, operativa entre 1965 y 1988, que tuvo un rol destacado en la lucha contra el movimiento guerrillero de Sendero Luminoso durante los años de la guerra interna (1980-1992).$^{13} \mathrm{Al}$ respecto, dice el hablante:

\footnotetext{
13 Sobre los procesos de la guerra interna y sus desarrollos en la poesía peruana de fines del siglo XX, véase De Lima 2013.
} 
por una cuestión puramente de azar / el arqueólogo ha amanecido en Ayacucho - Perú / plazuela de Huanta / la flor de retama nace de la sangre caída / de los hombres de las mujeres de los niños / alli mismito florece / y los sinchis matan estudiantes / buantinos de corazón // el arqueólogo piensa en una arqueología de lo humano. excavar en la misma plazuela de Huanta. excavar todas las fosas comunes de la tierra para saber si seríamos capaces de perdonar (Zariquiey 2005: 55).

De manera explícita se alude aquí a episodios de la violencia política peruana, específicamente, a la masacre de la plaza de la ciudad ayacuchana de Huanta en 1969, cuando el gobierno Revolucionario de las Fuerzas Armadas envió a los Sinchis a combatir la movilización ciudadana que se manifestaba públicamente en contra del fin a la gratuidad de la enseñanza obligatoria. El enfrentamiento acabó con la toma de la ciudad por parte de la unidad policial, la muerte y la desaparición de varios estudiantes, algunos de los cuales fueron llevados a las montañas para ser enterrados en fosas. A partir de este ominoso suceso nace el huayno ayacuchano "Flor de Retama” compuesto por Ricardo Dolorier e interpretado, entre otros, por Martina Portocarrero, y del que se apropia la voz poética del texto para darle un sentido documental a su expresión. ${ }^{14}$

\footnotetext{
14 Reproducimos la letra de la canción Flor de retama: "Vengan todos a ver / ¡Ay, vamos a ver! / En la Plazuela de Huanta,/ amarillito flor de retama,/ amarillito, amarillando flor de retama.// Donde la sangre del pueblo,/ ahí, se derrama;/ allí mismito florece / amarillito flor de retama,/ amarillito, amarillando / flor de retama.//¡Allí donde los cerros se encienden / hasta alcanzar la aurora!/ ¡Allí donde en tus faldas / se hacen buenas mujeres! / Tus nietos tienen que ser hombres / antes de ser niños / ¡Allí! ¡Amarillito, amarillando,/ crece la flor de la retama! // Por Cinco Esquinas están,/ los Sinchis entrando están.// Van a matar estudiantes/ huantinos de corazón,/ amarillito, amarillando/ flor de retama; van a matar campesinos / peruanos de corazón,/ amarillito, amarillando /flor de retama.// La sangre del pueblo /tiene rico perfume;/ la sangre del pueblo / tiene rico perfume; huele a jazmines, violetas,/ geranios y margaritas;/ a pólvora y dinamita.// Huele a jazmines, violetas,/ geranios y margaritas;/ a pólvora y dinamita/ ¡Carajo!/ ¡A pólvora y dinamita! / ¡Ay, carajo! /A pólvora y dinamita!”. Un análisis de esta canción y otras producciones culturales peruanas que son abordadas como "poéticas del duelo", se halla en Vich 2015. Véase también "Con la sed del ensueño", último poema del libro M.D.I.H. (2004) de Miguel Ildefonso, en el que también se reescribe e interviene la letra de esta canción.
} 
Del hecho histórico se desprende el siguiente poema de la sección, que el hablante define como "un pequeño artículo sobre el tema" (Zariquiey 2005: 55), en el cual el arqueólogo se dedica a estudiar los patrones funerarios de "esas tumbas silenciosas y disfrazadas de tierra carente de muertos" (Zariquiey 2005: 55), que engloba la imagen del Perú, territorio y paisaje, como fantasma, tumba, cadáver. El poema-artículo "Los patrones funerarios de las fosas comunes de Huamanga, Huanta, La Mar, Víctor Fajardo, Cangallo, Andahuaylas y Angaraes (enumeración interminable)" inicia con una cita del historiador Alberto Flores Galindo en su ensayo "La guerra silenciosa", incluido en el libro Violencia y campesinado (1985) que se refiere, como el texto anterior, a la violencia política del Perú en los años 80: "Durante ese año de 1983 se inauguran dos prácticas patentadas exclusivamente por el Estado y las fuerzas represivas: las desapariciones y las fosas clandestinas, llamadas en un expresivo neologismo «botaderos» de cadáveres: hoyos mal cubiertos en que aparecían amontonados los muertos" (Zariquiey 2005: 56). Precedido de la cita, que demarca aun más explícitamente el carácter documental de los hechos relatados, se encuentra la enumeración de los seis patrones funerarios que el arqueólogo observa en las fosas comunes de los sitios donde se produjeron enfrentamientos entre las fuerzas armadas del gobierno, los grupos guerrilleros y la población civil, y lo hace desde un registro "frío y aséptico de las características que aúnan lo hallado en las clandestinas tumbas colectivas preparadas por las fuerzas del orden durante los años de la guerra interna" (Chueca 2007: 74). Como advierte Chueca, el registro objetivo del poema en su condición de informe administrativo o inventario está dado, al igual que la mayoría de los textos de Tratado de arqueología peruana, por el título,

que hace evidente que el texto no busca darle preeminencia a alguna de las fosas sobre las demás [...] sino que pretende establecer una pauta general $[\ldots]$ que permita, en principio, más que emoción o indignación, un conocimiento objetivo de lo ocurrido y, a partir de ello, la comprensión de los hechos y de las circunstancias que los hicieron posible (2007: 76). 
Desde el registro burocrático-administrativo de la enunciación, los patrones funerarios resultan cuestionados o contradichos por la subjetividad de la mirada y la escritura del arqueólogo cuando este introduce ciertos comentarios que modifican su sintaxis y semántica. Así, por ejemplo, al hacer el reporte o informe técnico de los patrones funerarios de las fosas comunes de la región, detalla ciertas “precisiones semánticas” que permiten entender la calidad de víctimas de la represión del estado de esos cuerpos que yacen enterrados en las fosas. Los cuerpos, dice el primer patrón funerario, no son "colocados” en nichos, sino “arrojados” a ellos. El segundo patrón aclara que las pertenencias de los muertos (cuando vivos) quedaron en poder de los enterradores, es decir, de los “asesinos". El tercer patrón funerario puntualiza que "las únicas piezas metálicas aparecidas en los contextos funerarios son balas”, mientras que el sexto y último enumera las "enfermedades" que ocasionaban la muerte de los peruanos de esa época (1980 - 2000):

6.1) dinamita y pólvora

6.2) balas de pistola

6.3) balas de metralla

6.4) granadas en la boca

6.5) patadas con borcellez o bota militar

6.6) golpes de disímil carácter pero de intensidad siempre alta (Zariquiey 2005: 56)

Esta negación o resistencia al formato permite ponderar los alcances ético-políticos de la textualidad, en la medida en que el trabajo con el lenguaje resulta decidor para pensar el estatuto genérico-discusivo de esto que leemos, desde el pacto de la ficción poética, como un tratado de arqueología peruana. Con esto nos referimos a un texto que no es arqueología, sino poesía - una poesía fuera de sí, podríamos decir con Escobar (2004) o inespecífica, desde Garramuño (2015) —, sin que ello obste a que su discurso se aproxime y hasta se apropie del lenguaje y recursos expresivos de la arqueología, toda vez que es la operación interdisciplinaria de la escritura lo que permite contradecir y cuestionar en este texto los formatos 
burocráticos, pragmáticos, que fungen como relatos neutros o sin ideología. En esta dirección, Tratado de arqueología peruana emplea códigos y registros múltiples, poéticos y arqueológicos, encaminados a producir una memoria espacial del paisaje/territorio a partir de los restos materiales que, encontrados o no, dan vida a las comunidades históricas del presente y pasado. Por eso, la intervención del formato, sutil pero radical, devela la capacidad del lenguaje poético para construir miradas y posturas contrahegemónicas, a veces más descarnadas o desalentadoras, pero, tal vez por lo mismo, de mayor rigor y densidad estética, como sugiere, sin ir más lejos, la mirada acre del territorio en su condición de tumba silenciosa y anónima.

5. La selva: o la imposibilidad de una arqueología de la voz

Después de este crudo y desolador poema-inventario que cierra el capítulo de la sierra, inicia el tercer y último recorrido geográfico por el territorio nacional del Perú: la selva. En el relato inicial, "Los vestigios últimos de la tradición oral amazónica. La infructuosa arqueología de la voz”, el hablante comenta la vana tarea del arqueólogo por encontrar fuentes documentales de carácter oral que le den consistencia a su recorrido poético-etnográfico por la región amazónica. Acota, al respecto, que "durante cuatro años buscó a alguien que le hable. Era febrero del 2003 y ya estaba cansado. Ninguna arqueología era suficiente” (Zariquiey 2005: 61), confirmando una vez más el fracaso de su oficio al señalar que "aquí, los restos de las civilizaciones antiguas no corren la misma suerte que en los Andes; en los bosques tropicales todo termina siendo polvo o gusano. Igual sucede con la tradición oral” (61), como si la tarea de llevar a cabo una arqueología contextual a partir del testimonio oral fuese aun más infructuosa desde este entorno en particular, donde la tierra es "polvo o gusano", donde ni siquiera se conservan los huesos de los cadáveres.

Los últimos vestigios que encuentra el arqueólogo terminan constatando que en la selva la sobrevivencia humana - $-\mathrm{y}$, por extensión, la tradición oral amazónica- es todavía más difícil e, incluso, imposible, que en los territorios de la costa y la sierra antes 
explorados. ${ }^{15}$ A partir de esta constatación, el "Balance y perspectivas de la arqueología amazónica”"16 termina por confirmar que no hay testigos que recuerden el pasado ni evidencias que permitan la aproximación prospectiva hacia la cultura material de las comunidades amazónicas y su tradición oral:

como los bosques se acaban

y los ríos se desbordan

y no hay petróleo

nadie recuerde nuestra historia

una densa sombra

cae sobre nuestros muertos [...]

frustra buscar en la voz de alguien

el recuerdo de los primeros hombres de estas tierras

(los ancianos han dejado de hablar desde hace mucho)

tenemos tanta hambre

y tantas veces hemos caído enfermos

que ya hemos olvidado que antes de nosotros otros había

pensar en el desayuno del día siguiente cada noche

con la resignación de los que muerden el aire como panes

nos ha tragado la memoria

y la arqueología poco o nada nos dice de nosotros

la selva es una tierra sin pasado

y ni siquiera de eso ya nos acordábamos (Zariquiey 2005: 63-64)

15 Para Ana Molina, esta desarticulación del territorio amazónico obedece a una larga tradición de otredad cultural:

La Amazonía nunca se ha insertado completamente dentro de la historia nacional peruana, pues siempre ha cumplido el papel del otro en la concepción de la misma [...] dentro de los límites del actual estado-nación del Perú, la región amazónica siempre ha poseído el estatus del otro (ya se trate del periodo precolombino, del colonial o del republicano), pues su aislamiento geográfico y su difícil articulación a los centros de poder le otorgaron esta otredad radical en el imaginario de diversos grupos [...] es posible que este menosprecio hacia lo amazónico o la región del Antisuyo provenga de tiempos preincaicos remotos (2015: 7-9).

16 El texto se inicia con una cita-epígrafe del estudioso en desarrollo rural y comunidades nativas amazónicas Alejandro Camino Diez-Canseco, quien afirma: "La urgencia de la realidad cotidiana de la Amazonía contemporánea pareciera imponer un carácter inmediatista a nuestra reflexión sobre los procesos naturales y sociales de la región" (Zariquiey 2005: 63). 
Elocuentes resultan los dos últimos versos del poema: "la selva es una tierra sin pasado / y ni siquiera de eso ya nos acordábamos" (Zariquiey 2005: 64), puesto que la voz enunciativa vuelve a dar cuenta del territorio como un espacio inmaterial, inanimado, "tierra sin pasado" y, sobre todo, sin memoria. Las necesidades del día a día, la rudeza y precariedades del entorno o paisaje natural, "nos ha tragado la memoria", dice la voz plural del poema desde el lugar del testigo, que así como reconoce que "los ancianos han dejado de hablar desde hace mucho", también soporta la experiencia de la derrota: "una densa sombra / cae sobre nuestros muertos" (Zariquiey 2005: 63).

El sentimiento de frustración que atraviesa al personaje y al propio hablante-aprendiz de arqueólogo hace que esta sección, la última del recorrido geográfico, se cierre con dos relatos que van a constituir las "Inevidencias etnográficas" del tratado de arqueología peruana. La primera, "I Pequeño discurrir en contra de la etnografía como herramienta para los estudios arqueológicos", es determinante en constatar la imposibilidad del testimonio y la arqueología de la voz. De hecho, la nota al pie que la acompaña, en una apelación crítica al lector, niega lo planteado por el aprendiz de arqueólogo en la sección de la sierra, en la nota de campo "El arqueólogo viaja entre hombres vivos", donde este afirmaba que "los hombres del presente ayudan a comprender a los hombres del pasado" (Zariquiey 2005: 49). La nota al pie de esta sección, contradiciendo la afirmación anterior, asevera, en cambio, que "como puede apreciarse, este apartado contradice lo dicho en el que lleva por título La etnografía como método de una ciencia de los muertos. El lector puede sacar sus propias conclusiones" (Zariquiey 2005: 67).

Este pequeño discurrir en contra de la etnografía encuentra un agravante en la voz-personaje del "conferencista" norteamericano, quien luego de una larga estadía en el departamento de Ucayali ha escrito un "detallado estudio" sobre la cultura material de los shipibos y "ahora lo comparte con alumnos de antropología” (Zariquiey 2005: 67). El descriptivo relato del conferencista en torno a las vasijas (ollas, tazas, cubiletes) es contrastado por el comentario 
de un joven estudiante shipibo (“que radica en Lima”), quien opone su visión local a la del invitado internacional, sosteniendo que la importancia de las vasijas amazónicas se limita en la actualidad a su valor comercial: “mi abuela me dijo que la cerámica servía para vendérsela al turista y que si teníamos tazas, platos y ollas grandes o pequeñas era para satisfacerlo, cualquiera sea su gusto" (Zariquiey 2005: 68). El recuerdo/comentario del joven revela que el método etnográfico no tiene, en este caso, ninguna validez, pues, lo expresado por el conferencista no recoge la experiencia de la comunidad en sus prácticas culturales cotidianas.

El testimonio como resto de la tradición oral amazónica secunda la imposibilidad de hallar un sentido trascendente de los objetos observados prospectivamente, distante de una poesía amazónica basada en la visión mítica, la denuncia social y la crítica de los valores alienantes, como lo observa Ana Molina (2015) en ciertas producciones de la literatura loretana (principalmente en las de Germán Lequerica y del grupo urcututo). ${ }^{17}$ De este modo, la contraposición entre el estudio del investigador foráneo y la oralidad espontánea de un representante de la comunidad indígena globalizada (residente en la capital, Lima) también constata la imposibilidad de la etnografía como herramienta para los estudios arqueológicos del presente, y de la misma ciencia como conjunto de significados subjetivos de las comunidades del pasado, en tanto son los propios shipibos quienes (se) reconocen (en) el valor exótico, capitalista, de su cultura material. En ellos se ha perdido la memoria del origen, que conectaba el valor espiritual o afectivo de sus objetos de uso cotidiano con las creencias y costumbres arraigadas en el saber de

17 Según Molina,

lo mítico se convierte en la característica más importante de la idiosincrasia amazónica y en el elemento en común de todos los sectores sociales y culturales de la región (es decir, la identidad regional que permite vincular a los habitantes originales de la Amazonía y a los escritores mestizos) [...]. En esta versión de lo mítico articulado por los intelectuales loretanos, hay un fuerte vínculo con el compromiso político y la denuncia social, pues reivindicar el sustrato mítico amazónico y su pervivencia en la sociedad amazónica contemporánea implica una actitud política contestataria y de resistencia con respecto a los centros de poder (2015: 16-17). 
la tierra y la comunidad o, tal vez, dicha memoria ni siquiera existió en la mentalidad de los más jóvenes.

La otra inevidencia etnográfica es el relato del nieto de Shawán Pico, hombre "analfabeto pero una persona inteligente" (Zariquiey 2005: 69) $)^{18}$, según indica la cita de Elías, "amigo shipibo" con quien se inicia este último relato de Tratado de arqueología peruana. El texto se titula " $L$ a tradición oral contemporánea entre los shipibos del río Ucayali. La imagen mítica de Shawán Pico (Pedro Canallo), que falleció en la década de 1980", y consiste en una extensa crónica donde el "nieto favorito" recuerda su viaje en bote al mercado de Pucallpa en busca de provisiones con su abuelo Shawán Pico, contador de chistes y fundador de ocho comunidades: "Nueva Esperanza, Puerto Belén, Nueva Pucallpa, Puerto Jesús el Nazareno, Flor Naciente del Ucayali, Puerto Samaria, Nuevo Edén y Roaboya la Cristiana” (Zariquiey 2005: 70).

Esta inevidencia, al igual que la anterior, se presenta como constatación del fracaso de la arqueología — contextual y de la voz-, que intenta articular el aprendiz de arqueólogo del poemariotratado de Zariquiey, pues, así como el relato del conferencista y del joven estudiante shipibo revela el desencuentro entre el valor simbólico y el valor de cambio de la cultura material de la selva, el relato de este otro testigo indígena muestra al abuelo como un sujeto irresponsable, que llega a ser considerado líder por su comunidad solo por su astucia para engañar. Nuevamente, el relato del testigo expone una faceta negativa de la cultura ancestral como resto de una tradición desaparecida, venida a menos o, lisa y llanamente,

18 Las palabras de Elías, “amigo shipibo”, forman parte de la cita-epígrafe con que se da inicio al relato "La tradición oral contemporánea entre los shipibos del río Ucayali”:

Pedro se llamaba su nombre y su apodo era... este... Shawán Pico, nombre shipibo, nombre shipibo, Shawán Pico. Bueno... este... la verdad... dice... Shawán Pico era un hombre histórico. Él no contaba de lo que contaban a él, sino de lo que pasaba a él. Ese era. O sea que era su cuento propio, o sea su historia, se puede decir. Como Mario Vargas Llosa también, escritor ¿no? Él cuenta de su persona y era muy querido ese hombre. Además de eso, el hombre tenía ese don para animar a las personas. Bueno, por eso le querían a él. Era analfabeto pero una persona inteligente. No sabía leer y escribir pero era inteligente (Zariquiey 2005: 69). 
expropiada por el ethos neoliberal y su cultura del consumo, el individualismo y la propiedad privada. No es casual, de hecho, que el libro termine con estos dos relatos que desmitifican las culturas antiguas o que constatan su inexistencia. Ambos son considerados por el hablante como "in-evidencias etnográficas” que no tienen validez o legitimidad científica, por cuanto los significados subjetivos del pasado no son posibles de articularse desde la existencia de las comunidades antiguas, sus creencias, tradiciones, relatos, puesto que estas ya no existen y quienes las sobreviven no tienen memoria de sus orígenes. Son inevidencias, entonces, porque su condición de documento o fuente histórica está cuestionada y ha sido refutada en el relato mismo de su exposición como testimonio de carácter oral. Tanto el relato del joven estudiante shipibo que vive en Lima como el del nieto de Shawán Pico, si de algo son prueba, es de que la cultura material del pasado no existe en el presente o ha sido borrada por la intervención del capitalismo extractivista.

\section{La interdisciplina como exploración y los procedimientos de reescritura}

El recorrido anterior por las zonas geográfico-culturales del Perú permite corroborar que Tratado de arqueología peruana fluctúa entre dos tipos de saber y lenguaje: poesía y arqueología, al tratarse de una obra que transgrede las fronteras del contenido específico disciplinario para ser leída "simultánea o alternativamente como texto literario y/o texto etnográfico/etnológico” (Valenzuela 2015: 163). Es esta, por tanto, una manifestación intercultural, donde un sujeto antropólogo o arqueólogo entra en contacto con otro(s) para articular una memoria espacial del territorio nacional bajo la forma de un tratado (asumido este como un documento de carácter subjetivo) que indaga en las comunidades del pasado a través de sus restos materiales, desde donde se hace posible, a su vez, escribir la memoria del presente.

El recorrido geográfico y textual revela el punto de vista formal, incluso técnico, del poemario-tratado de Zariquiey, valga decir, su 
organización como un "documento de trabajo" (Chueca 2007: 74) cuya estructura interna (índice, marco teórico, capítulos de desarrollo, metodología, conclusiones) se perfila como una indagación literaria en torno a la cultura material y simbólica de las comunidades de la costa, la sierra y la selva. El hablante, aprendiz de arqueólogo, ha logrado delinear el territorio peruano desde la especificidad que separa o vincula una zona de otra, por medio de los restos encontrados en ellas gracias a las herramientas de la etnografía y los recursos propios de la poesía. En la costa, son las creencias de los pobladores y las señales de la naturaleza que se leen e interpretan sensorialmente como un oscuro presagio del destino de este territorio físico, humano y social llamado Perú. En la sierra, son los huesos de los cadáveres que documentan la memoria de la violencia política más reciente, resabio de las sucesivas violencias que pueblan la topografía del paisaje y sus sitios de memoria, como ocurre con el recinto arqueológico de Pachacamac. En la selva, donde menos evidencias hay del pasado, son los testimonios orales, casi inexistentes, de las nuevas generaciones que desconocen sus orígenes o han perdido su memoria.

El texto parece elaborar, por un lado, la memoria del Perú contemporáneo a partir de la noción de resto, una memoria que se expresa alegóricamente como una gran fosa común de la que es parte todo signo de vida (desde las aves o los cangrejos en la costa y los cuerpos/cadáveres que dejó la guerra interna en la sierra hasta el relato oral de los jóvenes shipibos en la selva amazónica); y, por otro lado, es a partir de esos restos que se urde, paralelamente, la memoria viva del presente en tanto tejido que no claudica la esperanza del sujeto enunciante por emprender su viaje por la geografía, aun cuando todas las manifestaciones del hombre y la naturaleza se presentan ante sus ojos como indicios de mala suerte (ruina, destrucción, fracaso). Así, a medida que se recorre el territorio y ponen en práctica los métodos de la ciencia social (arqueología contextual, prospección del espacio, seriación de objetos rituales), se va haciendo patente el empleo estético-ideológico de los lenguajes y formatos con los cuales Zariquiey da forma a la textualidad poético- 
etnográfica de su tratado de arqueología peruana: su dimensión interdisciplinaria e intercultural que recoge las voces de diversos actores sociales para mostrar las contradicciones y los lastres que esconde la idea de nación, las limitaciones de la propia ciencia social, pero, sobre todo, para ofrecer una mirada otra de la historia nacional como se aprecia, por ejemplo, en el episodio de las fosas comunes de Ayacucho, donde la etnografía es el método de una ciencia de los muertos cuyos restos descansan en las fosas “interminables”, enormes y calladas, que constituyen el paisaje humano y social del Perú.

Si nos aproximamos a este poemario como a un tratado en el sentido de una investigación académica o estudio formal, vemos que son sus procedimientos retóricos ${ }^{19}$ los que plantean la condición fallida de la nación peruana, esto es, su oscuro designio. De allí la importancia que adquieren los significados subjetivos de las comunidades del pasado en el marco de una investigación que es también y, sobre todo, un proyecto de escritura en torno a los límites y alcances culturales del oficio poético; es decir que su configuración interdisciplinaria, entre poesía y arqueología, moviliza la dinámica de exploración "contextual” del territorio (físicoverbal-simbólico) del Perú, así como de la propia palabra. Sobre esto, valga comentar que, además de los fragmentos que aportan los poemas-notas de campo ${ }^{20}$, aparecen con recurrencia en el tratado

19 Desde los rasgos visuales y tipográficas (uso de espacios, blancos de página, cortes versales, cursivas, mayúsculas, ilustraciones, guiones, paréntesis, entre otras), pasando por el uso sistemático de citas-epígrafes que juegan con el carácter científico/creativo del lenguaje, y la superposición de voces enunciativas que ocupan distintas posiciones ideológicas dentro del texto, hasta la apropiación de ciertos recursos o herramientas propias de la arqueología (notas de campo, seriaciones, anotaciones, informes o reportes técnicos, conclusiones arqueológicas), así como de textos artísticos y culturales que, gracias al montaje, se insertan en la obra para activar la posibilidad documental de la escritura poética.

20 Cada texto de Tratado de arqueología peruana corresponde a una nota de campo, ya sea del aprendiz de arqueólogo (narrador, cronista o hablante principal del texto), del personaje así nombrado "el arqueólogo" en la segunda sección del libro (la sierra), o de aquellos otros que toman la palabra para expresar en colectivo la idea de comunidad (los pobladores en la costa o los shipibos en la selva). 
de Zariquiey diversas notas al pie de página que hacen dialogar el cuerpo principal del texto con aquello que lo excede o que está fuera de sí. Varias de estas notas remiten a poemas anteriores o posteriores del mismo libro en la secuencia cronológica que sigue el poemario, mientras que otras sugieren una pista bibliográfica para completar o complementar la comprensión de lo que allí se expresa. Junto con ello, también es importante el cambio de registro que experimenta la enunciación de los poemas-notas, ya que algunos de estos mantienen una forma lírica clásica desde su organización en verso, al tiempo que otros se disponen en una prosa narrativa de carácter descriptivo e, incluso, serial cuando imitan la forma de un reporte administrativo o informe técnico, a la vez que otros se presentan bajo la modalidad de crónica-testimonial. Con todo ello, es posible sostener que Tratado de arqueología permana se articula, desde su macrotextualidad, como un documento de trabajo cuyos resultados dependen tanto de una interpretación subjetiva del objeto de estudio (el territorio/paisaje nacional) como de ciertas evidencias que el mismo hablante del poema llamará, hacia el final de su recorrido, "(in)evidencias etnográficas": in-evidencias o evidencias que no son tales, en la medida en que no resultan suficientes para atestiguar su condición de prueba de los significados subjetivos de las comunidades del pasado, que es como se entiende aquí la arqueología desde los planteamientos de Ian Hodder, y que podemos hacer extensivos a la postura enunciativa del poeta.

Por último, sobra decir que los registros y formatos utilizados para producir esta ficción del territorio/paisaje (lírico, etnográfico, informativo, narrativo, documental; verso, prosa, crónica, relato oral, nota de campo, diario personal, reporte, informe técnico) no solo evidencian un replanteamiento constante del lenguaje poético en la perspectiva de una literatura interdisciplinaria e intercultural, de acuerdo con las necesidades expresivas de los poemas-notas de campo (registros de la observación en terreno), sino que ellos suponen, además, un desafío radical de las concepciones acerca de lo que puede ser o no poesía hoy, para proponer, desde ahí, un intenso campo de trabajo con los materiales que, operando como 
documentos o fuentes históricas, se desautomatizan desde su inserción en un texto literario que demanda una lectura estética. De manera que todas las reflexiones, anotaciones o conclusiones —algunas de ellas, verdaderas artes poéticas- sitúan al Tratado de arqueología peruana de Roberto Zariquiey como un proyecto de escritura heterogéneo que recoge diversas voces y expresiones de lo humano-material, posibilitando una memoria del presente que es, también, una (re)escritura de la historia.

\section{A modo de conclusión}

En Tratado de arqueología peruana Roberto Zariquiey desarrolla una ficción del paisaje(s) y territorio(s) peruano a partir de los restos de la cultura material de sus sociedades, antiguas y modernas, que permiten reflexionar sobre la condición actual de comunidad, si acaso imaginada, de la nación. El poeta examina los paisajes del territorio desde una consciencia paisajera que recae en la prospección arqueológica de ciertos lugares, donde la historia/memoria del pasado se conserva en el presente en calidad de restos materiales. Y es a partir de esa aproximación —o "prospección" del espacio-que la voz enunciativa del texto, y las voces superpuestas o dialogantes con ella intentan desentrañar aquellos hechos que conectan la historia antigua (Chavín de Huántar) con la historia reciente vinculada, sobre todo, con el periodo de la violencia política (Flor de retama). $\mathrm{La}$ (re)escritura de la nación se encamina, de este modo, a documentar el hallazgo de los restos encontrados porque, por un lado, en ellos descansa la posibilidad de volver al pasado y de hacer de ese encuentro con la muerte - que es la arqueología contextual- un diálogo con la memoria de los vivos, y, por otro lado, porque la poesía, según el autor, es "patrimonio de la arqueología peruana", testimonio de lo que se leerá/conocerá en el futuro como historia/ memoria de lo que sucedió y sucede hoy en nuestros días. 


\section{Referencias bibliográficas}

Alvarado, Miguel

2005 "El espejo rápido: La consolidación de la antropología literaria chilena”. Nueva Revista del Pacífico. 50, 191-215.

CARrasco, Iván

2003 "La antropología poética como mutación disciplinaria”. Estudios Filológicos. 38, 7-17.

CARRASCO, Iván

2005 "Literatura intercultural chilena: Proyectos actuales". Revista Chilena de Literatura. 66, 63-84.

Chueca, Luis Fernando

2007 "Desentierros, des-identificaciones, desapariciones. Apuntes sobre representaciones de la violencia política en tres poemas peruanos recientes". Ajos E zafiros. 8-9, 69-86.

Degregori, Carlos Iván (Ed.)

2000 No hay país más diverso. Compendio de antropología peruana. Lima: IEP.

De Lima, Paolo

2013 Poesía y guerra interna en el Perú (1980-1992). Nueva YorkOntario: The Edwin Mellen Press.

EsCOBAR, Ticio

2004 El arte fuera de sí. Asunción: Centro de Artes Visuales-Museo del Barro. Fondec.

Fernández CoZman, Camilo

2016 Interculturalidad y sujeto migrante en la poesía de Vallejo, Cisneros y Watanabe. Lima: Universidad de Lima.

GARRAMUÑo, Florencia

2015 Mundos en común. Ensayos sobre la inespecificidad en el arte. Buenos Aires: FCE.

Guerrero, Gustavo

2018 Paisajes en movimiento. Literatura y cambio cultural entre dos siglos. Buenos Aires: Eterna Cadencia. 
HODDER, Ian

1994 Interpretación en arqueología. Corrientes actuales. Trad., María J. Aubet y J. A. Barceló. Barcelona: Crítica.

ILDEFONSO, Miguel

2004 M.D.I.H. Lima: Zignos.

López-Baralt, Mercedes

2005 Para decir al Otro. Literatura y antropología en nuestra América. Madrid: Iberoamericana - Vervuert.

Miranda, Paula y Roberto IbáÑEZ

2018 "Países y paisajes en Canto a su amor desaparecido de Raúl Zurita”. Nueva Revista del Pacífico. 69, 134-149.

Molina, Ana

2015 "La búsqueda de la voz propia en la lírica loretana a partir de tres hitos sucesivos: Los primeros cantores de la Amazonía; Germán Lequerica y el Grupo Urcututu”. Tesis de maestría. Pontificia Universidad Católica del Perú.

Olivares, Juan Carlos

1995 El umbral roto. Escritos en antropología poética. Santiago: Fondo Matta-Museo Chileno de Arte Precolombino.

Valenzuela, Pilar

2015 "Literatura antropológica en Chile: ¿Una literatura intercultural?”. Estudios filológicos. 56, 161-173.

Vich, Víctor

2015 Poéticas del duelo. Ensayos sobre arte, memoria y violencia política en el Perú. Lima: Instituto de Estudios Peruanos.

ZARIQUIEY, Roberto

2005 Tratado de arqueología peruana. Lima: PUCP.

Recepción: 16/01/2020

Aceptación: 14/01/2021 